\title{
AN APPLICATION OF GREY SYSTEM THEORY AND DEA IN STRATEGIC ALLIANCE IN VIETNAMESE AGRICULTURAL INDUSTRY
}

\section{THANH-TUYEN TRAN*}

\author{
Scientific Research Office, Lac Hong University, No. 10 Huynh Van Nghe, Bien Hoa City, Dong Nai \\ Province, Vietnam
}

${ }^{*}$ Corresponding author: copcoi2@gmail.com

\begin{abstract}
Collaboration is at the heart of every business success [1]. Indeed, every aspect of a business is dependent on a partnership one way or another. However, successful partnerships require a lot of factors and efforts from both sides in order to assure the necessary cooperation needed to harness the respective potency of each partner ([2]; [3]; [4]). Therefore, this study aims to develop tools which are Grey Theory and DEA models generate the effectiveness of enterprises in Vietnamese agricultural industry then offer an effective way to figure out the most suitable strategic partners. The most influenced enterprises are selected to collect realistic data from financial reports of Vietnam issued stock market in four consecutive financial years. The targeted decision making unit (DMU) has some potential partner for collaboration in the future, but they are also advised to stay away with some DMUs, which may make them even weaker after doing alliance. Although this research is specifically applied to the fertilizer industry, the proposed method could also be applied to other manufacturing industries.
\end{abstract}

Received 2018-07-29; accepted 2018-09-09; published 2018-11-02.

2010 Mathematics Subject Classification. 91B26.

Key words and phrases. strategic alliance; grey forecasting model (GM); data envelopment analyses (DEA); Vietnam fertilizer industry.

(C)2018 Authors retain the copyrights of their papers, and all open access articles are distributed under the terms of the Creative Commons Attribution License. 


\section{INTRODUCTION}

The fertilizer industry development relies on low labor costs, efficiency, large system of foreign exchange, an easy import and export procedures for exporters and the open policies for foreign investors ([5]; [6]). Currently, the fertilizer industry is facing more challenges such as how to maintain their competitiveness in today's fierce market, to diversify products, and divert from processing into other forms which can bring more advantages for the industry ([7]; [8]). In specific, there are three major problems: equipment and modern technology selection, maintaining a stable and capable workforce and floating capital. The problems cannot be overcome when firms are doing individually [9]. We would recommend finding the alliance partners for companies to solve those existing problems by combining Data Envelopment Analysis (DEA) and Grey Theory. Since errors in information are unavoidable, consequently, Grey theory and DEA Model are hired to forecast the business in the future and productively evaluatethe performance in firm's efficiency ranking [10].

The purpose of this research is to provide an assessment model based on Grey theory GM $(1,1)$ and Data Envelopment Analysis (DEA) and suggest an appropriated establishment of partnership after many thoughtful considerations.

\section{RESEACH METHODOLOGY}

\subsection{Grey Forecasting Model and Data Envelopment Analysis}

In Grey System Theory, GM (n, m) denotes a Grey model, where $\mathrm{n}$ is the order of the difference equation and $\mathrm{m}$ is the number of variables ([11]; [12]). Although various existing types of Grey models can be applied for forecasting, most of researchers, lecturers have paid focused on GM $(1,1)$ models in their prediction method due to its computational efficiency ([13]; [14]). It should be noted that in real time applications, with the complex data sets, the reduction in the computing time is even more important than the rest of parameters ([15]; [16]; [17]; [18]). 
GM $(1,1)$ is applied with the purpose of a forecasting for a series of time. And it can only been applied in non-negative data sequences, in this analysis, future values of the original data points can be predicted by Grey model because they are positive.

During recent years, some models have been presented to solve negative data in DEA models. However, they do not discriminate between efficient DMUs and only evaluate them as being efficient. In this part, we propose a model by which we discriminate between such DMUs it is "Slacks - based measure of efficiency" (SMB) introduced by Tone [19]. Then, we extend the "Slack - based measure of supper - efficiency" (Super - SBM) for DEA model with positive and negative inputs and outputs. In this model with $n$ DMUs with the input and output matrices $X=\left(x_{i j}\right) \in R^{m \times n}$ and $Y=\left(Y_{i j}\right) \in R^{s \times n}$, respectively. $\lambda$ is a non-negative vector in $R^{n}$. The vectors $S^{-} \in R^{m}$ and $S^{+} \in R^{s}$ indicate the input excess and output shortfall respectively. SBM model in fractional form is as follows [19]:

$$
\begin{aligned}
& \min \rho=\frac{1-\frac{1}{\mathrm{~m}} \sum_{i=1}^{m} s_{i}^{-} / x_{i 0}}{1+\frac{1}{s} \sum_{i=1}^{s} s_{i}^{-} / y_{i 0}} \\
& \text { s.t } x_{0}=X \lambda+s^{-}, y_{0}=Y \lambda-s^{+}, \lambda \geq 0, \mathrm{~s}^{-} \geq 0, \mathrm{~s}^{+} \geq 0 .
\end{aligned}
$$

Let an optimal solution for SBM be $\left(p^{*}, \lambda^{*}, s^{-^{*}}, s^{+*}\right)$. A DMU $\left(x_{0}, y_{0}\right)$ is SBM-efficient, if $p^{*}=1$. This condition is equivalent to $S^{-*}=0$ and $S^{+*}=0$, no input excesses and no output shortfalls in any optimal solution. SBM is non-radial and deals with input/output slacks directly. The SBM returns and efficiency measure between 0 and 1.

The top onehave the full effective status indicated by unity. According to super-SBM model by Tone [20], assuming that the DMU $\left(x_{0}, y_{0}\right)$ is SBM-efficient, $p^{*}=1$, super-SBM model is as follows: 


$$
\begin{gathered}
\min \delta=\frac{\frac{1}{\mathrm{~m}} \sum_{i=1}^{m} \bar{x}_{i} / x_{i 0}}{\frac{1}{s} \sum_{r=1}^{s} \overline{y_{r}} / y_{r 0}} \\
\text { s.t } \bar{x} \geq \sum_{j=1, \neq 0}^{n} \lambda_{j} x_{j}, \bar{y} \leq \sum_{j=1, \neq 0}^{n} \lambda_{j} x_{j}, \bar{y} \geq x_{0} \text { and } \overline{\mathrm{y}} \leq y_{0}, \bar{y} \overline{\mathrm{y}} \geq y_{0}, \lambda \geq 0 .
\end{gathered}
$$

Comparable to other DEA models, determine how to deal with negative outputs in model efficiency evaluation is fairly important [21]. But the properly role of negative data is effectiveness measurement, therefore DEA-Solver pro 4.1 Manuel had new change as below

Let us suppose $y_{r o} \leq 0$. it is defined $\bar{y}_{r}^{+}$and $y_{-r}^{+}$by

$$
\begin{aligned}
& \bar{y}_{r}^{+}=\max _{j=1, \ldots, n}\left\{y_{r j} \mid y_{r j}>0\right\}, \\
& \bar{y}_{r}^{+}=\min _{j=1, \ldots, n}\left\{y_{r j} \mid y_{r j}>0\right\} .
\end{aligned}
$$

(1) $\bar{y}_{r}^{+}=y_{-r}^{+}=1$, the term is replaced by $s_{r}^{+} / \frac{y_{-r}^{+}\left(\bar{y}_{r}^{+}-y_{-r}^{+}\right)}{\bar{y}_{r}^{+}-y_{r 0}}$ $s_{r}^{+} / \frac{\left(y_{-r}^{+}\right)^{2}}{B\left(\bar{y}_{r}^{+}-y_{r 0}\right)}$

Where $B$ is a large positive number, (in DEA-Solver $B=100$ ).

\subsection{Development of research}

In this study, Grey Theory and DEA model are combined in a group of methodical evaluation models. The development of research in this paper is implemented by the data information of Vietnamese Fertilizer Industry and also selected all related documentations as references. Then after subject confirming and proceeding industrial analysis, the development of this study is presented in Figure 1 as below: 


\section{FIGURE 1: STUDY DEVELOPMENT}

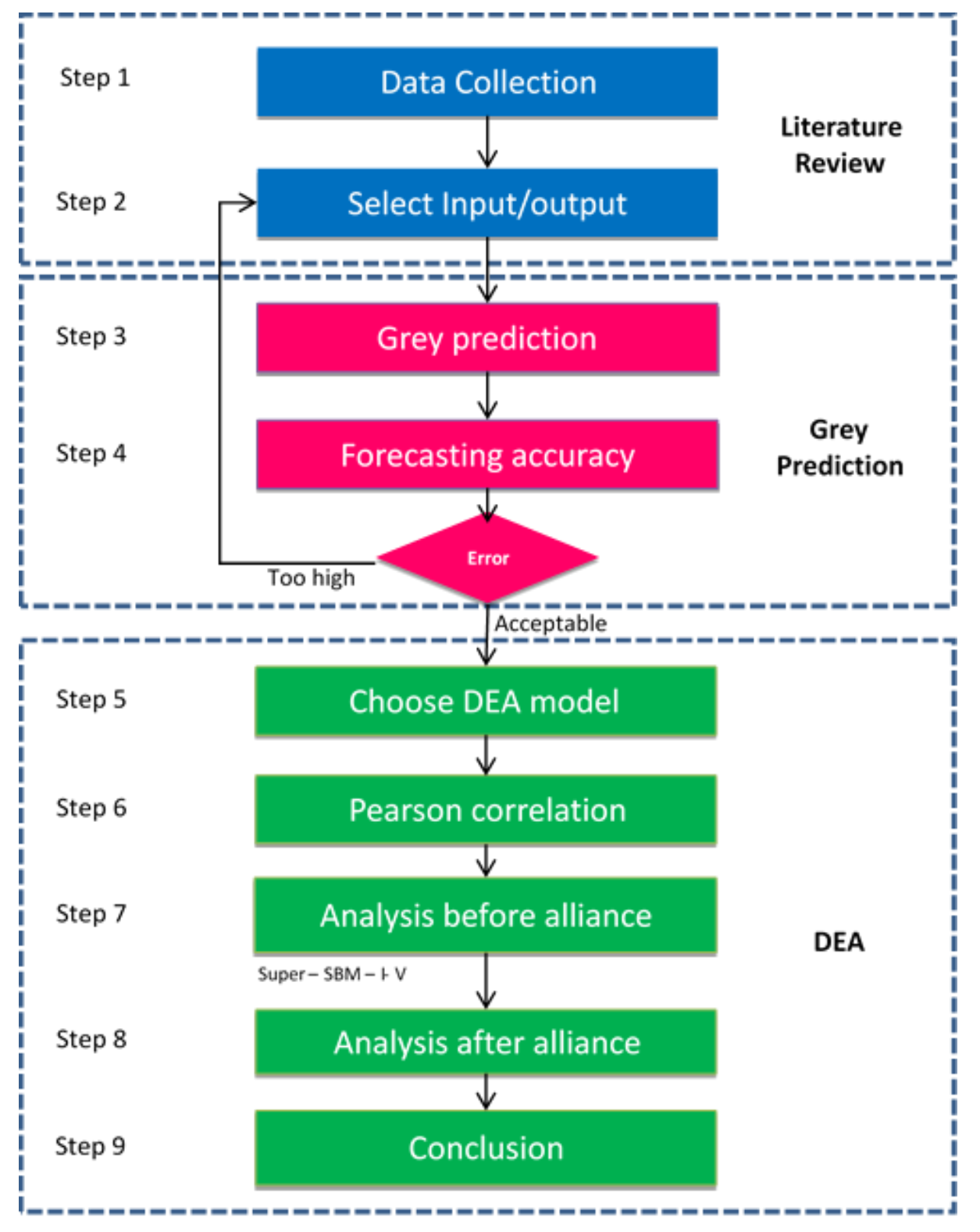




\section{APPLICABLE CASE RESULT AND ANALYSIS}

\subsection{Data Collection}

To apply the research on Grey Forecasting model and DEA literature review, three main participations are selected as fixed assets, cost of goods sold, operating costs which are essential to the sources of fertilizer industry. And we select the net sales, operating profit, net profits as our output factors owing to the essential index to analyze the company's financial effectiveness. We show the realistic data of 2016 which are gained from the financial statement that they are selected at Vietnam issued stock market website with the Vietnam currency unit. The companies are listed in Table 1.

\section{TABLE 1: COMPANIES LIST}

\begin{tabular}{|c|c|l|}
\hline $\begin{array}{l}\text { Number } \\
\text { order }\end{array}$ & Code & \multicolumn{1}{c|}{ Companies } \\
\hline 1 & A & Petrovietnam Fertilizer and Chemicals \\
\hline 2 & B & Petrovietnam Ca Mau Fertilizer JSC \\
\hline 3 & C & BinhDien Fertilizer JSC \\
\hline 4 & D & Lam Thao Fertilizers and Chemicals JSC \\
\hline 5 & E & The Southern Fertilizers JSC \\
\hline 6 & F & Quang Binh Import and Export JSC \\
\hline 7 & G & NinhBinh Phosphate Fertilizer JSC \\
\hline 8 & H & Central PetroVietnam Fertilizer And Chemicals \\
\hline 9 & I & South-East PetroVietnam Fertilizer \& Chemicals \\
\hline 10 & K & Van Dien Fused Magnesium Phosphate \\
\hline 11 & N & South-West PetroVietnam Fertilizer and \\
\hline
\end{tabular}

To apply the research on Grey Forecasting model and DEA literature review, three main participations are selected as fixed assets, cost of goods sold, operating costs which are essential to the sources of fertilizer industry. And we select the net sales, operating profit, net profits as our output factors owing to the essential index to analyze the company's financial effectiveness. We show the realistic data of 2016 which are gained from the financial statement that they are selected at Vietnam issued stock market website with the Vietnam currency unit. 
TABLE 2: INPUT AND OUTPUT FACTORS OF COMPANIES IN FERTILIZER INDUSTRY IN 2016

\begin{tabular}{|c|c|c|c|c|c|c|}
\hline \multirow[t]{2}{*}{ Company } & \multicolumn{3}{|c|}{$\begin{array}{l}\text { Input } \\
\text { (Units: Volume million, \$thousand) }\end{array}$} & \multicolumn{3}{|c|}{$\begin{array}{l}\text { Input } \\
\text { (Units: Volume million, \$thousand) }\end{array}$} \\
\hline & Fix assets & $\begin{array}{c}\text { Cost of } \\
\text { Goods } \\
\text { sold }\end{array}$ & $\begin{array}{c}\text { Operating } \\
\text { Cost }\end{array}$ & Net sales & $\begin{array}{c}\text { Net } \\
\text { profits }\end{array}$ & $\begin{array}{c}\text { Operating } \\
\text { profit }\end{array}$ \\
\hline $\mathrm{A}$ & $1,910,477$ & $5,528,946$ & $1,248,517$ & $7,924,787$ & $1,164,775$ & $1,385,216$ \\
\hline B & $8,754,407$ & $3,595,508$ & 963,306 & $4,910,171$ & 624,340 & 632,709 \\
\hline $\mathrm{C}$ & 742,125 & $5,038,820$ & 489,927 & $5,942,917$ & 350,100 & 421,064 \\
\hline $\mathrm{D}$ & 193,750 & $3,233,437$ & 562,608 & $3,964,661$ & 138,150 & 171,686 \\
\hline$E$ & 150,386 & $2,105,100$ & 149,510 & $2,338,362$ & 90,589 & 102,510 \\
\hline $\mathrm{F}$ & 272,675 & $4,300,199$ & 224,435 & $4,495,270$ & 13,561 & 16,690 \\
\hline$G$ & 9,559 & 447,691 & 75,801 & 546,139 & 19,334 & 23,145 \\
\hline $\mathrm{H}$ & 45,939 & $1,910,249$ & 60,932 & $1,997,252$ & 25,168 & 31,289 \\
\hline I & 35,167 & $2,071,763$ & 69,801 & $2,165,958$ & 23,353 & 26,457 \\
\hline $\mathrm{K}$ & 16,853 & 689,058 & 176,225 & 907,609 & 44,432 & 54,398 \\
\hline $\mathrm{N}$ & 31,797 & $2,153,810$ & 56,339 & $2,237,995$ & 28,117 & 35,149 \\
\hline
\end{tabular}

Sources: Financial statements of companies

The Grey Model $(1,1)$ is utilized to predict the input and output factors values for each decision making unit in 2016 and 2017. In the Table 2, we take the total deposits of $\mathrm{DMU}_{1}$ as an example to explain how to calculation. Other variables are calculated in the same way.

In this research, we use 5 periods of data (2012-2016) to forecast the input and output variables value in 2017 and 2018. Here, we select the fixed assets of company A as example to calculate in detail the procedure as following (Table 3 and Table 4). 
TABLE 3: INPUTS AND OUTPUTS DATA OF ALL DMUS IN 2017

\begin{tabular}{|c|c|c|c|c|c|c|}
\hline Company & $\begin{array}{l}\text { Fixed } \\
\text { Assets }\end{array}$ & $\begin{array}{l}\text { Cost of } \\
\text { goods sold }\end{array}$ & $\begin{array}{l}\text { Operating } \\
\text { costs }\end{array}$ & Net sales & Net profits & $\begin{array}{c}\text { Operating } \\
\text { profit }\end{array}$ \\
\hline A & $\begin{array}{c}1,685,963.9 \\
0\end{array}$ & $\begin{array}{c}5,458,073.0 \\
4\end{array}$ & $\begin{array}{c}1,328,062.5 \\
6\end{array}$ & $\begin{array}{c}7,787,165.4 \\
2\end{array}$ & $898,571.13$ & $\begin{array}{c}1,119,514.3 \\
5\end{array}$ \\
\hline B & $\begin{array}{c}8,276,456.7 \\
4\end{array}$ & $\begin{array}{c}3,173,383.2 \\
0\end{array}$ & $\begin{array}{c}1,125,406.6 \\
9\end{array}$ & $\begin{array}{c}4,671,239.0 \\
4\end{array}$ & $711,194.13$ & $736,011.19$ \\
\hline $\mathrm{C}$ & $895,353.32$ & $\begin{array}{c}4,770,331.4 \\
5\end{array}$ & $529,771.77$ & $\begin{array}{c}5,687,218.0 \\
4\end{array}$ & $366,951.03$ & $437,892.40$ \\
\hline $\mathrm{D}$ & $202,773.07$ & $\begin{array}{c}3,262,600.7 \\
2\end{array}$ & $592,196.17$ & $\begin{array}{c}3,969,420.5 \\
3\end{array}$ & $156,268.90$ & $194,096.28$ \\
\hline $\mathrm{E}$ & $107,026.31$ & $\begin{array}{c}1,991,256.2 \\
2\end{array}$ & $129,892.69$ & $\begin{array}{c}2,187,819.0 \\
1\end{array}$ & $77,099.39$ & $84,327.45$ \\
\hline $\mathrm{F}$ & $343,824.05$ & $\begin{array}{c}5,616,309.6 \\
7\end{array}$ & $318,580.84$ & $\begin{array}{c}5,883,841.4 \\
6\end{array}$ & $42,496.76$ & $52,313.94$ \\
\hline G & $7,996.72$ & $381,027.75$ & $65,632.55$ & $461,389.60$ & $12,934.22$ & $16,429.11$ \\
\hline $\mathrm{H}$ & $41,678.48$ & $\begin{array}{c}1,902,502.9 \\
5\end{array}$ & $64,176.59$ & $\begin{array}{c}1,983,763.9 \\
2\end{array}$ & $22,869.33$ & $27,362.72$ \\
\hline I & $38,872.59$ & $\begin{array}{c}1,858,105.7 \\
1\end{array}$ & $70,642.69$ & $\begin{array}{c}1,948,927.1 \\
1\end{array}$ & $21,974.00$ & $24,062.58$ \\
\hline $\mathrm{K}$ & $3,458.66$ & $684,922.27$ & $188,073.55$ & $906,731.96$ & $43,991.94$ & $50,259.14$ \\
\hline $\mathrm{N}$ & $37,166.07$ & $\begin{array}{c}2,043,969.4 \\
9\end{array}$ & $58,719.15$ & $\begin{array}{c}2,127,340.1 \\
8\end{array}$ & $29,031.92$ & $33,935.78$ \\
\hline
\end{tabular}

Source: Calculating by author 
TABLE 4: INPUTS AND OUTPUTS DATA OF ALL DMUs IN 2018

\begin{tabular}{|c|c|c|c|c|c|c|}
\hline Company & $\begin{array}{l}\text { Fixed } \\
\text { Assets }\end{array}$ & $\begin{array}{l}\text { Cost of } \\
\text { goods sold }\end{array}$ & $\begin{array}{l}\text { Operating } \\
\text { costs }\end{array}$ & Net sales & Net profits & $\begin{array}{c}\text { Operating } \\
\text { profit }\end{array}$ \\
\hline A & $\begin{array}{c}1,545,418.0 \\
9\end{array}$ & $5,075,411.34$ & $\begin{array}{c}1,352,662.8 \\
3\end{array}$ & $7,232,792.69$ & $740,254.75$ & $926,069.79$ \\
\hline B & $\begin{array}{c}7,625,272.6 \\
4\end{array}$ & $2,821,149.52$ & $\begin{array}{c}1,208,493.7 \\
2\end{array}$ & $4,320,868.44$ & $727,436.45$ & $769,271.25$ \\
\hline $\mathrm{C}$ & $\begin{array}{c}1,083,730.4 \\
0\end{array}$ & $4,517,465.95$ & $590,576.54$ & $5,483,607.79$ & $401,330.76$ & $475,474.11$ \\
\hline $\mathrm{D}$ & $207,478.12$ & $3,135,209.31$ & $602,198.50$ & $3,747,812.28$ & $117,641.82$ & $144,764.92$ \\
\hline $\mathrm{E}$ & $70,160.26$ & $1,937,956.48$ & $118,505.13$ & $2,113,179.50$ & $70,160.84$ & $74,911.50$ \\
\hline $\mathrm{F}$ & $430,583.44$ & $7,382,882.89$ & $536,768.63$ & $7,716,047.30$ & $41,852.48$ & $51,236.70$ \\
\hline $\mathrm{G}$ & $6,545.77$ & $343,641.55$ & $56,991.30$ & $410,420.12$ & $9,649.57$ & $12,546.64$ \\
\hline $\mathrm{H}$ & $37,782.09$ & $1,782,638.32$ & $69,989.40$ & $1,860,623.01$ & $19,980.84$ & $23,313.15$ \\
\hline I & $36,493.75$ & $1,622,388.64$ & $69,521.73$ & $1,706,539.05$ & $20,017.98$ & $20,720.02$ \\
\hline $\mathrm{K}$ & $1,636.32$ & $673,631.40$ & $202,180.74$ & $894,452.32$ & $37,039.20$ & $41,643.87$ \\
\hline $\mathrm{N}$ & $39,446.23$ & $1,892,235.76$ & $63,977.69$ & $1,975,691.83$ & $28,427.04$ & $32,268.06$ \\
\hline
\end{tabular}

\subsection{Evaluating Process}

Table 5 indicated that the forecasting value of $\mathrm{DMU}_{\mathrm{s}}$ are good because most of MAPE of DMU less than $10 \%$ and the MAPE average of all thirty commercial banks is $10.48 \%$ (less than $20 \%)$ which confirm GM $(1,1)$ model suitable in this case study. Therefore, this means the results in table 5 have a good reliability. 
TABLE 5: AVERAGE MAPE ERROR OF DMUs

\begin{tabular}{|c|c|c|c|c|c|c|c|}
\hline Company & $\begin{array}{l}\text { Fixed } \\
\text { Assets }\end{array}$ & $\begin{array}{c}\text { Cost of } \\
\text { goods sold }\end{array}$ & $\begin{array}{c}\text { Operating } \\
\text { costs }\end{array}$ & $\begin{array}{l}\text { Net } \\
\text { sales }\end{array}$ & $\begin{array}{l}\text { Net } \\
\text { profits }\end{array}$ & $\begin{array}{c}\text { Operating } \\
\text { profit }\end{array}$ & $\begin{array}{c}\text { Average } \\
\text { MAPE of } \\
\text { DMUs }\end{array}$ \\
\hline A & 4.36 & 4.87 & 3.71 & 4.02 & 17.88 & 12.17 & 7.84 \\
\hline $\mathrm{C}$ & 2.48 & 1.05 & 8.41 & 2.32 & 14.30 & 15.14 & 7.28 \\
\hline $\mathrm{D}$ & 8.88 & 0.70 & 6.63 & 0.66 & 4.61 & 4.90 & 4.40 \\
\hline $\mathrm{E}$ & 4.73 & 4.45 & 3.75 & 5.11 & 21.41 & 21.47 & 10.15 \\
\hline $\mathrm{F}$ & 24.93 & 4.73 & 5.39 & 4.17 & 4.66 & 5.59 & 7.28 \\
\hline G & 53.28 & 1.26 & 14.29 & 1.80 & 101.01 & 104.12 & 45.96 \\
\hline $\mathrm{H}$ & 4.10 & 4.59 & 3.34 & 4.69 & 14.97 & 14.69 & 7.73 \\
\hline I & 0.15 & 4.58 & 4.70 & 4.29 & 8.43 & 8.49 & 4.40 \\
\hline $\mathrm{K}$ & 12.75 & 2.79 & 4.48 & 2.80 & 2.38 & 4.06 & 4.88 \\
\hline $\mathrm{N}$ & 37.71 & 0.98 & 2.35 & 1.44 & 11.15 & 5.94 & 9.93 \\
\hline
\end{tabular}

Source: Calculating by author

\subsection{Alliance Setting-up Stages}

DEA expects that the input and output factors must be metis tonicity ([22]; [23]). Prior to the procedure of DEA analysis, we have to ensure the connection between input and output factors and tonicity ([24]; [25]; [26]; [27]; [28]). Therefore, in this paper, we employ Pearson correlation analysis to see if our data fits the assumption of DEA. Correlation coefficient between input and output variables are high than 0.6, which exhibits a highly positive correlation and well complies with the prerequisite condition of the DEA model.

Here, we run the software of Super-SBM-I-V by choosing the realistic data of 2016 to rank the companies' effectiveness before alliances. The empirical results are obtained in the below table. 
TABLE 6: EFFICIENCY, RANKING BEFORE STRATEGIC ALLIANCES

\begin{tabular}{|c|c|c|}
\hline Rank & DMU & Score \\
\hline 1 & G & 1.875656 \\
\hline 2 & K & 1.703822 \\
\hline 3 & F & 1.377278 \\
\hline 4 & $\mathrm{~N}$ & 1.321511 \\
\hline 5 & $\mathrm{D}$ & 1.268671 \\
\hline 6 & $\mathrm{C}$ & 1.213142 \\
\hline 7 & A & 1 \\
\hline 8 & I & 0.94212 \\
\hline 9 & $\mathrm{E}$ & 0.937486 \\
\hline 10 & $\mathrm{H}$ & 0.86823 \\
\hline 11 & B & 0.612298 \\
\hline
\end{tabular}

Source: Calculating by author

Here, company Eis chosen as target Company for alliance considering to the outcome of data ranking of 2016 before strategic alliance by reason of couple of reasons. Firstly, company E acquired the point less than 1 all of the period from 2012 - 2016, implying that they did not have good business performance. Subsequently, they should boldly develop their effectiveness by alliance model. Secondly, company $\mathrm{E}$ is in major position in the fertilizer industry. To implement our empirical research, we combine E with the rest of DMUs to reach 21 virtual alliances.

Finally, we use the software of DEA-Solver for calculation of Super-SBM-I-V model for 21 DMUs. Table 7 shows the score and ranking results of virtual alliance in 2018. 
TABLE 7: PERFORMANCE RANKING OF VIRTUAL ALLIANCE

\begin{tabular}{|c|c|c|c|}
\hline Rank & DMU & Score & Group \\
\hline 1 & K & 4.44656 & \\
\hline 2 & $\mathrm{G}$ & 1.887691 & \\
\hline 3 & $E+F$ & 1.675027 & 1 \\
\hline 4 & $\mathrm{~N}$ & 1.189458 & \\
\hline 5 & $E+D$ & 1.178774 & 1 \\
\hline 6 & B & 1.127153 & \\
\hline 7 & $E+K$ & 1.11175 & 2 \\
\hline 8 & $\bar{A}$ & 1.098635 & \\
\hline 9 & $E+N$ & 1.090146 & 2 \\
\hline 10 & $\mathrm{E}$ & 1.076125 & \\
\hline 11 & $E+C$ & 1.053355 & 2 \\
\hline 12 & $\mathrm{C}$ & 1.012596 & \\
\hline 13 & D & 1.006937 & \\
\hline 14 & $E+A$ & 1 & 2 \\
\hline 15 & $E+G$ & 0.991406 & 2 \\
\hline 16 & $E+I$ & 0.976105 & 3 \\
\hline 17 & $\mathrm{E}+\mathrm{H}$ & 0.967737 & 3 \\
\hline 18 & I & 0.932377 & \\
\hline 19 & $\mathrm{H}$ & 0.918227 & \\
\hline 20 & $\mathrm{~F}$ & 0.902863 & \\
\hline 21 & $E+B$ & 0.681111 & 3 \\
\hline
\end{tabular}

Source: Calculating by author

In this examination, enterprise $\mathrm{E}$ is established as the objective enterprise which was positioned as the ten in comparison to the other 11 DMUs in 2016.The Southern Fertilizer JSC (SFG) takes a hand in manufacturing, sale of fertilizer and other chemical products. The Company's main products include Nitrogen-Phosphorous-Potassium (NPK) fertilizer, organic 
NPK fertilizer, solid and liquid Yogen fertilizer, Phosphorous fertilizer, sulfuric acid, and agricultural organic minerals among others.The Southern Fertilizer JSC looks for strategic alliances. As indicated by the positioning of virtual cooperation, the examinations of observational outcomes split into three gatherings and translate as underneath:

First, the companies, which acquires brighter outcome after strategic alliance and also put their partnership more effectively, are the first prioritized candidate. Both corporationF and D helped the E to develop the result into a higher level after strategic alliance, which can be observed in Table 8.

\section{TABLE 8: THE FIRST PRIORITY IN ALLIANCE STRATEGY}

\begin{tabular}{|c|c|c|c|}
\hline Rank & DMU & Score & Group \\
\hline 3 & E+F & 1.675027 & 1 \\
\hline 5 & E+D & 1.178774 & 1 \\
\hline
\end{tabular}

Source: Calculating by author

Second, the DMU which increases performance after strategic alliance while other DMU gets worst is the second priority. Total five companies in this group are shown in Table 9.

TABLE 9: THE SECOND PRIORITY IN ALLIANCE STRATEGY

\begin{tabular}{|c|c|c|c|}
\hline Rank & DMU & Score & Group \\
\hline 7 & E + K & 1.11175 & 2 \\
\hline 9 & E + N & 1.090146 & 2 \\
\hline 11 & E + C & 1.053355 & 2 \\
\hline 14 & E + A & 1 & 2 \\
\hline 15 & E + G & 0.991406 & 2 \\
\hline
\end{tabular}

Source: Calculating by author

Thirdly, the DMUs which become worse and worse after strategic alliances are not suggested in this study. It is unnecessary to put in any effort for partnership because no advantages between both candidates and target candidates. Table 10 presented 3 companies in the group as below 


\section{TABLE 10: THE THIRD PRIORITY IN ALLIANCE STRATEGY}

\begin{tabular}{|c|c|c|c|}
\hline Rank & DMU & Score & Group \\
\hline 16 & E + I & 0.976105 & 3 \\
\hline 17 & E + H & 0.967737 & 3 \\
\hline 21 & E + B & 0.681111 & 3 \\
\hline
\end{tabular}

Source: Calculating by author

The importance of strategic alliance has been consistently emphasized as the key factors of business survival in the era of globalization. It helps companies to reduce risk and easily penetrate into the market. However, it is a big challenge to have a successful strategic alliance. Application of a strategic alliance can give rise to less than competitiveness or cause large enterprises to become even larger and small enterprises even smaller.

\section{Recommendations and Conclusions}

At this moment, more and more competition dramatically arises in fertilizer industry. According to the Viet Nam Fertilizer Association, the domestic fertilizer industry has experienced a growth in output, but lacking of competitive ability. The industry still continues to widely apply the usage of old-fashioned production technology while the world's fertilizer industry uses many modern technologies to reduce production costs. In long term, local fertilizer factories will lose their market shares or even have to dissolve if they do not embrace new creation advancement in technology.Although the industry counts around600 companiesbut most of them are small-medium sized.Products made in Vietnam are low-tomedium quality.Supplementary to this, like any existing market, one of the essential challenges is operating the management of the supply chain, in-depth understanding the import requirements and ensuring that the product can be delivered to the customer and/or consumer.Input/ output factors fluctuate in different periods, which makes "business future" in uncertain success. Therefore, in this research, we propose a new methodology which combines the GM $(1,1)$ model and DEA model to find the right alliance partners for Target Company under several inputs and outputs.

Many related subjects of strategic alliance have been already done research by many scholars and experts. However, this study provides firms with a method tolimit the possibilities of risks, 
creates the mode of penetration. But how strategic alliance opens up for firms to be roaring successful is the enormous challenge.

This research concentrates on the connection between key collusion and firms' execution of Vietnamese Fertilizer by using GM $(1,1)$ model and DEA model. This study reaches some conclusions through a series of literature reviews and empirical results.

1. The $\operatorname{GM}(1,1)$ model helps the enterprises to predict what will happen in the future regarding particular elements: fixed assets, cost of goods sold, operating costs, net profits, operating profit, which are important to the firm's efficiency in doing business based on the realistic data and information in the past time. However, there are alwaysexistent errors in predicting processes, thus the MAPE is utilized to ensure whatever collection of inputs or outputs is almost precise or not. In this examination, the range of MAPE values from $2 \%$ to $20 \%$, whichguarantee that GM $(1,1)$ delivers high accurateness.

2. This study shows that the DEA model is based on the resource-based theory. The SuperSBM model was used to assess the11 firms separately and calculate the operational performance of 21simulated decision making units for strategic alliances. Thanks to this methodology, we can simply divide 11 candidates into three groups.

In this study, company E, among famous fertilizer companies in Vietnam, is an objective company for strategic alliance with the others 10 firms. We observe the two companies which are the best candidates because profits are generated for both sides: target company $\mathrm{E}$ and 2 candidate companies due to the effective alliance. This factled to the outstanding efforts from both: collaborative innovation agreement and renewal products. The second priority is a group of companies with five companies and Target Company should carefully consider when implementing alliance because they can get the risk after strategic alliances. The third group includes companies: E, $\mathrm{H}$ \& B, which are unnecessarily to be cared because there is no advantage for two alliances. 


\section{REFERENCES}

[1] Z. S. Hassanzadeh, S. R. Hosseini and F. Honarbakhsh, Study of the educational factors contributing to realization of the objectives of entrepreneurial university. Int. J. Adv. Appl. Sci., 2(10) (2015), 1-12.

[2] J. C. Anderson and J. A. Narus, A model of distributor firm and manufacturer firm working partnerships. J. Market., 54(1990), 42-58.

[3] D. T. Wilson, An integrated model of buyer-seller relationships. J. Acad. Market. Sci., 23(4) (1995), 335-345.

[4] A. Walter, T. A. Müller, G. Helfert and T. Ritter, Functions of industrial supplier relationships and their impact on relationship quality. Industr. Market. Manag., 32(2) (2003), 159-169.

[5] R. Pomfret, Growth and transition: why has China's performance been so different?. J. Comparative Econ., 25(3) (1997), 422-440.

[6] F. Yuruk and P. Erdogmus, Finding an optimum location for biogas plant: a case study for Duzce, Turkey. Neural Comput. Appl., 29(1) (2018), 157-165.

[7] T. T. Tran, Forecasting strategies and analyzing the numbers of incoming students: Case in Taiwanese vocational schools. Int. J. Adv. Appl. Sci., 4(9) (2017), 86-95.

[8] T. T. Tran, A strategic alliance study by performance evaluation and forecasting techniques: A case in the petroleum industry. Int. J. Adv. Appl. Sci., 5(2) (2018), 136-147.

[9] M. Mendola, Agricultural technology adoption and poverty reduction: A propensity-score matching analysis for rural Bangladesh. Food Policy, 32(3) (2007), 372-393.

[10] N. T. Nguyen and T. T. Tran, A two-stage study of grey system theory and DEA in strategic alliance: An application in Vietnamese fertilizing industry. Int. J. Adv. Appl. Sci., 5(9) (2018), 73-81.

[11] T. T. Tran, Evaluating and forecasting performance using past data of an industry: An analysis of electronic manufacturing services industry. Int. J. Adv. Appl. Sci., 3(12) (2016), 5-20.

[12] N. T. Nguyen and T. T. Tran, Optimizing mathematical parameters of Grey system theory: an empirical forecasting case of Vietnamese tourism. Neural Comput. Appl., (2017), https://doi.org/10.1007/s00521-0173058-9.

[13] S. Liu, J. Forrest and Y. Yang, A brief introduction to grey systems theory. Grey Syst., Theory Appl., 2(2) (2012), 89-104.

[14] Y. Y. Tai, J. Y. Lin, M. S. Chen, and M. C. Lin, A grey decision and prediction model for investment in the core competitiveness of product development. Technol. Forecast. Social Change, 78(7) (2011), 1254-1267.

[15] S. Chtourou, M. Chtourou and O. Hammami, A hybrid approach for training recurrent neural networks: application to multi-step-ahead prediction of noisy and large data sets. Neural Comput. Appl., 17(3)(2008), 245254.

[16] T. T. Tran, Evaluating and forecasting performance using past data of an industry: An analysis of electronic manufacturing services industry. Int. J. Adv. Appl. Sci., 3(12) (2016), 5-20.

[17] N. T. Nguyen and T. T. Tran, Mathematical development and evaluation of forecasting models for accuracy of inflation in developing countries: a case of Vietnam. Discrete Dynamics in Nature and Society, 2015. 
[18] N. T. Nguyen and T. T. Tran, Raising opportunities in strategic alliance by evaluating efficiency of logistics companies in Vietnam: a case of Cat Lai Port. Neural Comput. Appl., (2018). https://doi.org/10.1007/s00521018-3639-2.

[19] K. A. Tone, Slacks-based measure of efficiency in data envelopment analysis, Eur. J. Oper. Res., 130(2001), 498-509.

[20] K. A. Tone, A slacks-based measure of super-efficiency in data envelopment analysis, Eur. J. Oper. Res., 143(2002), 32-41.

[21] J. Tongzon, Efficiency measurement of selected Australian and other international ports using data envelopment analysis. Transport. Res. Part A: Policy Practice, 35(2)(2001), 107-122.

[22] W. Fan, J. Xu, Y. Wu, W. Yu, J. Jiang, Z. Zheng and C. Tian, Parallelizing sequential graph computations. In Proceedings of the 2017 ACM International Conference on Management of Data, 2017, (pp. 495-510). ACM.

[23] M. Sozio and A. Gionis, The community-search problem and how to plan a successful cocktail party. In Proceedings of the 16th ACM SIGKDD international conference on Knowledge discovery and data mining (2010), (pp. 939-948). ACM.

[24] A. Hailu and T. S. Veeman, Non-parametric productivity analysis with undesirable outputs: an application to the Canadian pulp and paper industry. Amer. J. Agric. Econ., 83(3) (2001), 605-616.

[25] G. J. Morton, D. E. Cummings, D. G. Baskin, G. S. Barsh and M. W. Schwartz, Central nervous system control of food intake and body weight. Nature, 443 (2006), 289-295.

[26] J. Liu, Q. Xu, H. Chen, L. Zhou, J. Zhu and Z. Tao, Group decision making with interval fuzzy preference relations based on DEA and stochastic simulation. Neural Comput. Appl., (2017), https://doi.org/10.1007/s00521-017-3254-7.

[27] A. Al-Refaie, C. W. Wu and M. Sawalheh, DEA window analysis for assessing efficiency of blistering process in a pharmaceutical industry. Neural Comput. Appl., (2018), https:/ /doi.org/10.1007/s00521-017-3303-2. [28] R. Mahmoudi, A. Emrouznejad amd M. Rasti-Barzoki, A bargaining game model for performance assessment in network DEA considering sub-networks: a real case study in banking. Neural Comput. Appl., (2018), https:/ / doi.org/10.1007/s00521-018-3428-y. 


\section{APENDIX}

INPUT AND OUTPUT FACTORS OF TARGET DMUs IN 2012

\begin{tabular}{|c|c|c|c|c|c|c|}
\hline Companies & Fix Assets & $\begin{array}{c}\text { Cost of } \\
\text { goods sold }\end{array}$ & $\begin{array}{c}\text { Operating } \\
\text { cost }\end{array}$ & Net sales & Net profits & $\begin{array}{c}\text { Operating } \\
\text { profit }\end{array}$ \\
\hline A & $2,371,392$ & $8,997,366$ & $1,318,093$ & $13,321,852$ & $3,067,647$ & $3,574,740$ \\
\hline B & $12,436,315$ & $2,967,940$ & 410,051 & $4,076,182$ & 736,671 & 730,296 \\
\hline C & 425,142 & $6,869,767$ & 366,813 & $7,422,968$ & 158,867 & 197,199 \\
\hline $\mathrm{D}$ & 219,612 & $3,495,007$ & 502,080 & $4,494,851$ & 394,091 & 509,684 \\
\hline $\mathrm{E}$ & 563,219 & $2,544,853$ & 202,360 & $2,840,282$ & 98,79 & 119,108 \\
\hline F & 31,870 & $2,302,833$ & 92,291 & $2,391,848$ & 2,038 & 2,382 \\
\hline G & 19,403 & 551,271 & 142,841 & 770,310 & 63,697 & 79,316 \\
\hline $\mathrm{H}$ & 65,240 & $2,347,980$ & 43,250 & $2,440,980$ & 43,649 & 53,177 \\
\hline I & 30,373 & $3,546,253$ & 64,083 & $3,649,449$ & 40,376 & 50,015 \\
\hline $\mathrm{K}$ & 42,682 & 659,152 & 153,577 & 875,652 & 68,800 & 90,547 \\
\hline $\mathrm{N}$ & 26,853 & $3,087,222$ & 43,145 & $3,178,573$ & 53,324 & 66,068 \\
\hline
\end{tabular}


INPUT AND OUTPUT FACTORS OF TARGET DMUs IN 2013

\begin{tabular}{|c|c|c|c|c|c|c|}
\hline Companies & Fix Assets & $\begin{array}{c}\text { Cost of } \\
\text { goods sold }\end{array}$ & $\begin{array}{c}\text { Operating } \\
\text { cost }\end{array}$ & Net sales & Net profits & $\begin{array}{c}\text { Operating } \\
\text { profit }\end{array}$ \\
\hline A & $2,368,444$ & $7,011,191$ & $1,194,639$ & $10,363,418$ & $2,179,191$ & $2,586,225$ \\
\hline B & $11,209,745$ & $5,065,121$ & 830,907 & $6,263,118$ & 531,710 & 495,135 \\
\hline C & 466,150 & $5,895,935$ & 379,110 & $6,585,110$ & 261,684 & 318,832 \\
\hline $\mathrm{D}$ & 173,294 & $3,668,449$ & 531,103 & $4,768,477$ & 446,820 & 580,370 \\
\hline $\mathrm{E}$ & 537,410 & $2,343,321$ & 185,888 & $2,638,857$ & 115,398 & 140,514 \\
\hline $\mathrm{F}$ & 57,542 & $1,861,569$ & 57,992 & $1,939,946$ & 21,348 & 25,760 \\
\hline G & 17,316 & 579,585 & 112,844 & 735,370 & 40,451 & 46,074 \\
\hline $\mathrm{H}$ & 61,656 & $2,447,841$ & 48,183 & $2,542,168$ & 36,380 & 48,519 \\
\hline I & 44,993 & $3,218,254$ & 76,630 & $3,336,440$ & 31,409 & 42,486 \\
\hline K & 76,255 & 731,509 & 145,336 & 959,652 & 80,543 & 105,472 \\
\hline $\mathrm{N}$ & 23,564 & $2,811,818$ & 44,765 & $2,890,025$ & 30,394 & 40,606 \\
\hline
\end{tabular}


INPUT AND OUTPUT FACTORS OF TARGET DMUs IN 2014

\begin{tabular}{|c|c|c|c|c|c|c|}
\hline Companies & Fix Assets & $\begin{array}{c}\text { Cost of } \\
\text { goods sold }\end{array}$ & $\begin{array}{c}\text { Operating } \\
\text { cost }\end{array}$ & Net sales & Net profits & $\begin{array}{c}\text { Operating } \\
\text { profit }\end{array}$ \\
\hline A & $2,295,454$ & $7,121,096$ & $1,276,866$ & $9,548,850$ & $1,134,458$ & $1,557,395$ \\
\hline B & $11,004,157$ & $4,586,281$ & 840,164 & $6,044,143$ & 820,887 & 798,534 \\
\hline C & 426,608 & $5,696,732$ & 336,303 & $6,377,225$ & 288,549 & 356,146 \\
\hline $\mathrm{D}$ & 207,529 & $3,856,523$ & 587,436 & $4,985,068$ & 438,723 & 553,003 \\
\hline E & 519,572 & $1,962,180$ & 180,825 & $2,237,982$ & 100,898 & 115,315 \\
\hline $\mathrm{F}$ & 299,256 & $2,503,864$ & 72,899 & $2,655,043$ & 64,419 & 84,372 \\
\hline G & 15,787 & 533,179 & 106,828 & 682,933 & 36,468 & 44,322 \\
\hline $\mathrm{H}$ & 56,177 & $2,252,616$ & 46,832 & $2,348,012$ & 40,198 & 51,855 \\
\hline I & 52,297 & $2,712,487$ & 69,519 & $2,821,395$ & 29,570 & 39,741 \\
\hline K & 19,131 & 713,894 & 144,563 & 929,122 & 85,211 & 87,618 \\
\hline $\mathrm{N}$ & 38,205 & $2,470,498$ & 42,643 & $2,548,198$ & 31,887 & 40,914 \\
\hline
\end{tabular}


INPUT AND OUTPUT FACTORS OF TARGET DMUS IN 2015

\begin{tabular}{|c|c|c|c|c|c|c|}
\hline Companies & Fix Assets & $\begin{array}{c}\text { Cost of } \\
\text { goods sold }\end{array}$ & $\begin{array}{c}\text { Operating } \\
\text { cost }\end{array}$ & Net sales & Net profits & $\begin{array}{c}\text { Operating } \\
\text { profit }\end{array}$ \\
\hline A & $1,853,676$ & $6,612,424$ & $1,355,133$ & $9,764,947$ & $1,522,461$ & $1,855,678$ \\
\hline B & $9,848,606$ & $3,950,628$ & $1,145,494$ & $5,582,239$ & 712,460 & 712,527 \\
\hline C & 652,335 & $5,278,378$ & 425,014 & $6,037,884$ & 280,234 & 337,002 \\
\hline E & 191,584 & $3,673,450$ & 590,926 & $4,651,235$ & 306,285 & 391,334 \\
\hline F & 171,237 & $3,319,407$ & 113,278 & $3,516,965$ & 77,278 & 93,609 \\
\hline G & 11,508 & 427,693 & 83,221 & 532,533 & 17,638 & 21,653 \\
\hline H & 50,728 & $2,369,227$ & 51,944 & $2,452,136$ & 27,958 & 34,392 \\
\hline I & 50,050 & $2,562,297$ & 78,202 & $2,673,131$ & 27,286 & 33,264 \\
\hline & 17,974 & 722,029 & 164,166 & 956,801 & 65,183 & 81,636 \\
\hline & 34,790 & $2,519,510$ & 46,905 & $2,600,069$ & 32,042 & 37,566 \\
\hline & & & 141,198 & $2,337,950$ & 86,046 & 99,837 \\
\hline & & & & & & \\
\hline
\end{tabular}


INPUT AND OUTPUT FACTORS OF TARGET DMUs IN 2016

\begin{tabular}{|c|c|c|c|c|c|c|}
\hline Companies & Fix Assets & $\begin{array}{c}\text { Cost of } \\
\text { goods sold }\end{array}$ & $\begin{array}{c}\text { Operating } \\
\text { cost }\end{array}$ & Net sales & Net profits & $\begin{array}{c}\text { Operating } \\
\text { profit }\end{array}$ \\
\hline A & $1,910,477$ & $5,528,946$ & $1,248,517$ & $7,924,787$ & $1,164,775$ & $1,385,216$ \\
\hline B & $8,754,407$ & $3,595,508$ & 963,306 & $4,910,171$ & 624,340 & 632,709 \\
\hline C & 742,125 & $5,038,820$ & 489,927 & $5,942,917$ & 350,100 & 421,064 \\
\hline D & 193,750 & $3,233,437$ & 562,608 & $3,964,661$ & 138,150 & 171,686 \\
\hline E & 150,386 & $2,105,100$ & 149,510 & $2,338,362$ & 90,589 & 102,510 \\
\hline F & 272,675 & $4,300,199$ & 224,435 & $4,495,270$ & 13,561 & 16,690 \\
\hline G & 9,559 & 447,691 & 75,801 & 546,139 & 19,334 & 23,145 \\
\hline I & 45,939 & $1,910,249$ & 60,932 & $1,997,252$ & 25,168 & 31,289 \\
\hline & 31,797 & $2,153,810$ & 56,339 & $2,237,995$ & 28,117 & 35,149 \\
\hline & 16,853 & 689,058 & 176,225 & 907,609 & 44,432 & 54,398 \\
\hline & $2,071,763$ & 69,801 & $2,165,958$ & 23,353 & 26,457 \\
\hline & & & & & & \\
\hline N & 35,167 & & & & & \\
\hline
\end{tabular}


FORECASTING RESULTS FOR DMUs FROM 2013 TO 2016

\begin{tabular}{|c|c|c|c|c|c|c|c|}
\hline $\begin{array}{l}\text { DMU } \\
\text { s }\end{array}$ & $\begin{array}{l}\text { Fixed } \\
\text { Assets }\end{array}$ & $\begin{array}{l}\text { Cost of } \\
\text { goods sold }\end{array}$ & $\begin{array}{l}\text { Operating } \\
\text { costs }\end{array}$ & Net sales & Net profits & $\begin{array}{c}\text { Operating } \\
\text { profit }\end{array}$ & $\begin{array}{c}\text { Year } \\
\mathrm{s}\end{array}$ \\
\hline \multirow{4}{*}{$\mathrm{A}$} & $2,388,126.86$ & $\begin{array}{c}7,299,812.9 \\
9\end{array}$ & $\begin{array}{c}1,234,054.8 \\
1\end{array}$ & $\begin{array}{c}10,463,402.5 \\
1\end{array}$ & $\begin{array}{c}1,950,911.0 \\
8\end{array}$ & $\begin{array}{c}2,390,966.2 \\
6\end{array}$ & 2013 \\
\hline & $2,189,047.14$ & $\begin{array}{c}6,788,028.1 \\
8\end{array}$ & $\begin{array}{c}1,256,913.7 \\
3\end{array}$ & $9,718,506.95$ & $\begin{array}{c}1,607,186.3 \\
0\end{array}$ & $\begin{array}{c}1,977,823.3 \\
6\end{array}$ & 2014 \\
\hline & $2,006,563.15$ & $\begin{array}{c}6,312,124.2 \\
5\end{array}$ & $\begin{array}{c}1,280,196.0 \\
8\end{array}$ & $9,026,640.92$ & $\begin{array}{c}1,324,021.2 \\
8\end{array}$ & $\begin{array}{c}1,636,068.7 \\
7\end{array}$ & 2015 \\
\hline & $1,839,291.45$ & $\begin{array}{c}5,869,585.6 \\
1\end{array}$ & $\begin{array}{c}1,303,909.6 \\
9\end{array}$ & $8,384,029.22$ & $\begin{array}{c}1,090,746.2 \\
1\end{array}$ & $\begin{array}{c}1,353,367.0 \\
8\end{array}$ & 2016 \\
\hline \multirow{4}{*}{ B } & $\begin{array}{c}11,486,844.5 \\
3\end{array}$ & $\begin{array}{c}5,080,520.1 \\
3\end{array}$ & $846,388.72$ & $6,380,816.98$ & $649,771.36$ & $616,742.81$ & 2013 \\
\hline & $\begin{array}{c}10,583,070.0 \\
2\end{array}$ & $\begin{array}{c}4,516,601.3 \\
7\end{array}$ & $908,876.29$ & $5,902,217.90$ & $664,610.90$ & $644,613.17$ & 2014 \\
\hline & $9,750,403.67$ & $\begin{array}{c}4,015,275.4 \\
9\end{array}$ & $975,977.22$ & $5,459,516.59$ & $679,789.36$ & $673,742.99$ & 2015 \\
\hline & $8,983,250.76$ & $\begin{array}{c}3,569,594.9 \\
1\end{array}$ & $\begin{array}{c}1,048,032.1 \\
0\end{array}$ & $5,050,020.50$ & $695,314.46$ & $704,189.16$ & 2016 \\
\hline \multirow{4}{*}{ C } & $417,145.17$ & $\begin{array}{c}5,931,482.1 \\
3\end{array}$ & $343,035.68$ & $6,580,120.63$ & $256,466.57$ & $315,013.78$ & 2013 \\
\hline & $504,910.07$ & $\begin{array}{c}5,617,066.4 \\
1\end{array}$ & $382,407.74$ & $6,344,543.24$ & $280,494.99$ & $342,049.55$ & 2014 \\
\hline & $611,140.18$ & $\begin{array}{c}5,319,317.2 \\
3\end{array}$ & $426,298.75$ & $6,117,399.84$ & $306,774.63$ & $371,405.63$ & 2015 \\
\hline & $739,720.48$ & $\begin{array}{c}5,037,351.1 \\
2\end{array}$ & $475,227.36$ & $5,898,388.48$ & $335,516.41$ & $403,281.17$ & 2016 \\
\hline D & $184,995.92$ & $\begin{array}{c}3,826,074.9 \\
9\end{array}$ & $553,820.83$ & $4,994,870.56$ & $486,537.02$ & $627,238.47$ & 2013 \\
\hline
\end{tabular}




\begin{tabular}{|c|c|c|c|c|c|c|c|}
\hline & $189,288.48$ & $\begin{array}{c}3,676,682.1 \\
8\end{array}$ & $563,175.00$ & $4,716,012.59$ & $366,273.13$ & $467,820.04$ & 2014 \\
\hline & $193,680.64$ & $\begin{array}{c}3,533,122.5 \\
6\end{array}$ & $572,687.15$ & $4,452,722.96$ & $275,736.48$ & $348,919.26$ & 2015 \\
\hline & $198,174.71$ & $\begin{array}{c}3,395,168.3 \\
6\end{array}$ & $582,359.97$ & $4,204,132.48$ & $207,578.99$ & $260,238.22$ & 2016 \\
\hline \multirow{4}{*}{$\mathrm{E}$} & $579,545.95$ & $\begin{array}{c}2,219,522.9 \\
9\end{array}$ & $187,488.58$ & $2,513,688.16$ & $112,428.28$ & $135,410.05$ & 2013 \\
\hline & $379,916.84$ & $2,160,113.2$ & $171,051.66$ & $2,427,931.32$ & $102,310.31$ & $120,290.25$ & 2014 \\
\hline & $249,051.53$ & $\begin{array}{c}2,102,293.7 \\
4\end{array}$ & $156,055.74$ & $2,345,100.16$ & $93,102.91$ & $106,858.71$ & 2015 \\
\hline & $163,263.79$ & $\begin{array}{c}2,046,021.8 \\
7\end{array}$ & $142,374.50$ & $2,265,094.85$ & $84,724.13$ & $94,926.93$ & 2016 \\
\hline \multirow{4}{*}{$\mathrm{F}$} & $139,782.22$ & $\begin{array}{c}1,880,837.6 \\
4\end{array}$ & $39,532.09$ & $1,989,414.54$ & $45,174.60$ & $56,854.20$ & 2013 \\
\hline & $175,054.39$ & $\begin{array}{c}2,472,442.7 \\
4\end{array}$ & $66,606.59$ & $2,608,910.65$ & $44,489.72$ & $55,683.47$ & 2014 \\
\hline & $219,227.03$ & $\begin{array}{c}3,250,133.3 \\
3\end{array}$ & $112,223.73$ & $3,421,315.50$ & $43,815.23$ & $54,536.84$ & 2015 \\
\hline & $274,546.03$ & $4,272,441.3$ & $189,082.87$ & $4,486,700.12$ & $43,150.96$ & $53,413.83$ & 2016 \\
\hline \multirow{4}{*}{ G } & $17,812.17$ & $575,917.57$ & $115,441.56$ & $736,926.97$ & $41,751.20$ & $48,301.58$ & 2013 \\
\hline & $14,580.27$ & $519,408.91$ & $100,242.40$ & $655,519.01$ & $31,148.48$ & $36,887.10$ & 2014 \\
\hline & $11,934.78$ & $468,444.85$ & $87,044.38$ & $583,104.14$ & $23,238.31$ & $28,170.06$ & 2015 \\
\hline & $9,769.29$ & $422,481.34$ & $75,584.03$ & $518,688.91$ & $17,336.94$ & $21,513.00$ & 2016 \\
\hline \multirow{2}{*}{$\mathrm{H}$} & $61,718.53$ & $2,468,162.4$ & $45,368.49$ & $2,563,400.06$ & $39,247.53$ & $51,926.86$ & 2013 \\
\hline & $55,948.66$ & $2,312,659.2$ & $49,477.75$ & $2,404,278.59$ & $34,290.40$ & $44,241.91$ & 2014 \\
\hline
\end{tabular}




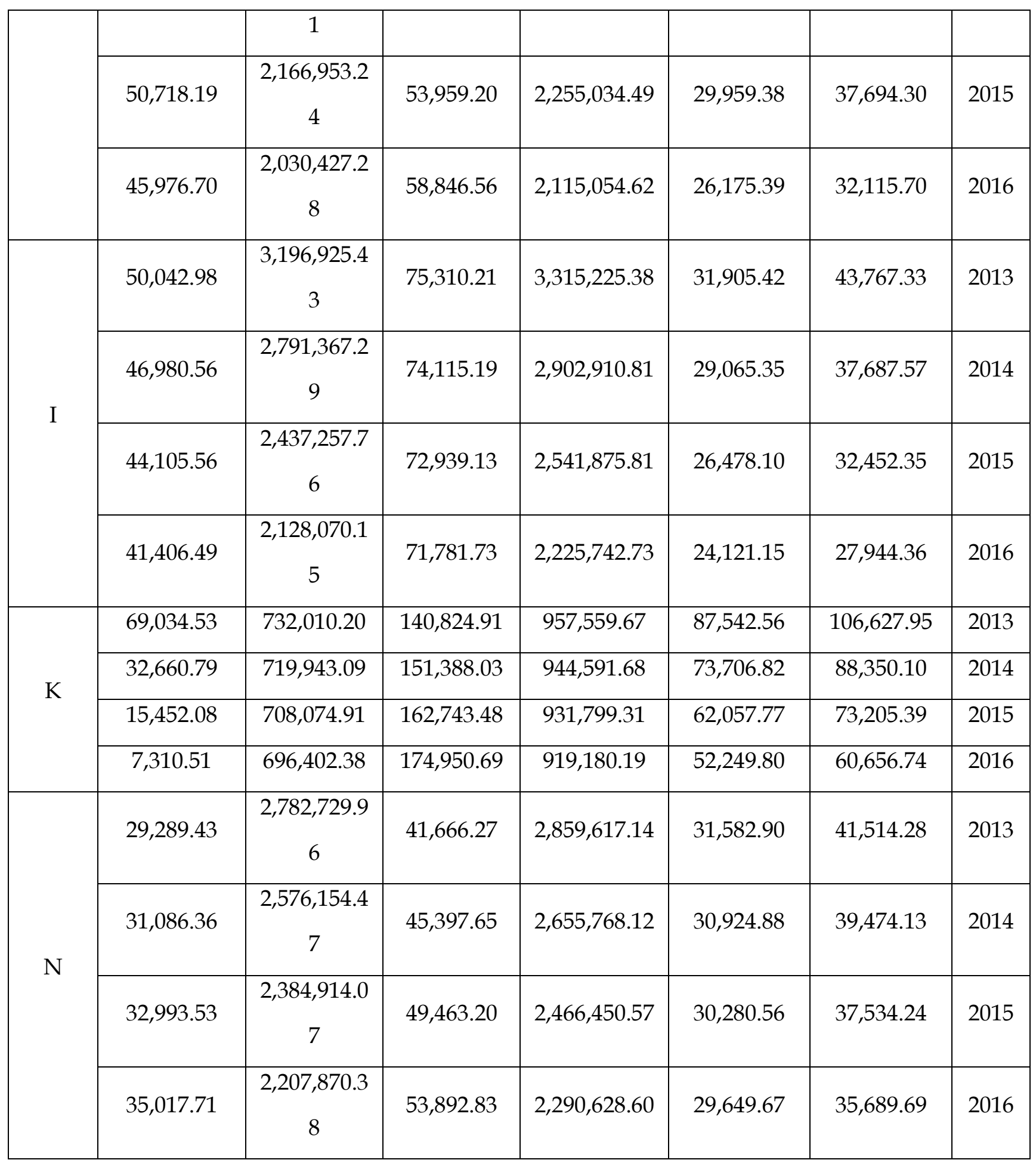


MAPE CALCULATING FOR DMUs FROM 2013 TO 2016

\begin{tabular}{|c|c|c|c|c|c|c|c|}
\hline DMUs & $\begin{array}{l}\text { Fixed } \\
\text { Assets }\end{array}$ & $\begin{array}{c}\text { Cost of } \\
\text { goods sold }\end{array}$ & $\begin{array}{l}\text { Operating } \\
\text { costs }\end{array}$ & Net sales & $\begin{array}{c}\text { Net } \\
\text { profits }\end{array}$ & $\begin{array}{c}\text { Operating } \\
\text { profit }\end{array}$ & Ye \\
\hline & 0.831046126 & 4.116590049 & 3.299390862 & 0.9647832 & 10.475444 & 7.549951686 & 2013 \\
\hline & 4.6355 & 4.677 & .562597015 & 1.7767265 & 1.669969 & 26.99 & 2014 \\
\hline & 8.2477 & 4.5414 & 7586 & 7.56 & 13.034141 & 11.8 & 2015 \\
\hline & 3.7260 & 6.1610 & 4.436678796 & 5.7950103 & 3556301 & 2992 & 2016 \\
\hline & 086 & 2899 & 6 & 3 & 8 & 57 & 2013 \\
\hline & 3.82661733 & 1.519305739 & 8.178437474 & 2.3481426 & 19.037468 & 19.27542536 & 2014 \\
\hline & 0.997119035 & 1.636385084 & 14.7985746 & 2.1984442 & 4.5856106 & 5.443163906 & 2015 \\
\hline & 2.614 & 0.72 & 8.795 & 2.84 & 130 & $11.2 \mathrm{c}$ & 2016 \\
\hline & 363 & 911 & 55 & 4 & 9 & 02 & 2013 \\
\hline & 18.35 & 1.398 & 13.70 & 0.5 & .7912 & 3.95 & 2014 \\
\hline & 6.314979658 & 0.775602403 & 0.302283726 & 1.3169487 & 9.4708804 & 10.20873198 & 2015 \\
\hline & 0.32 & 4 & 31 & 0.7492704 & 5 & 88 & 2016 \\
\hline & 103 & 4.296 & 516 & & 84 & 9689 & 2013 \\
\hline & 8.7893 & 4.6632 & 4.129982405 & 5.39 & 6.513808 & 15.40 & 2014 \\
\hline & 1.094371267 & 3.82004489 & 3.086485535 & 4.2679427 & 9.9738885 & 10.83849993 & 2015 \\
\hline & 2 & 9 & 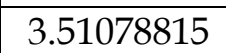 & & 33 & & 2016 \\
\hline & 7.840 & 5.283 & 0.8610 & 4.74 & 2.5734587 & 3.632341309 & 2013 \\
\hline & 26.878 & 10.08741602 & 5.404861424 & 8.48 & 1.39 & 4.314484942 & 2014 \\
\hline & 56.43350477 & 0.746200265 & 10.52263082 & 0.3058301 & 8.201324 & 7.033176797 & 2015 \\
\hline & 8.56315681 & 2.806428744 & 4.772587155 & 3.1332679 & 6.4741546 & 7.397391298 & 2016 \\
\hline & 14 & 1.03 & 31.8 & 55 & 45 & 38 & 2013 \\
\hline & 41.50346437 & 1.25491082 & 8.631675732 & 1.7375368 & 30.936956 & 34.00243411 & 2014 \\
\hline & 28.02549984 & 2.086929224 & 0.93069136 & 2.7196603 & 43.301808 & 41.73974439 & 2015 \\
\hline & 0.686175888 & 0.645496541 & 15.75161309 & 0.1906421 & 218.19896 & 220.0349318 & 2016 \\
\hline \multirow{2}{*}{ c } & 2.865376084 & 0.632767883 & 2.30190748 & 0.2117258 & 3.2142614 & 4.834787255 & 2013 \\
\hline & 7.643815581 & 2.58263864 & 6.164 & 4.0141558 & 14.586828 & 16.7747376 & 2014 \\
\hline
\end{tabular}




\begin{tabular}{|c|c|c|c|c|c|c|c|}
\hline \multirow{2}{*}{} & 3.708543236 & 9.52829413 & 4.594251804 & 9.4963393 & 31.751415 & 30.09770429 & 2015 \\
\cline { 2 - 8 } & 2.199958954 & 5.631039699 & 0.286241911 & 5.0262094 & 10.329263 & 7.051216505 & 2016 \\
\hline \multirow{3}{*}{$\mathrm{H}$} & 0.101422786 & 0.830178572 & 5.841293482 & 0.8351949 & 7.8821559 & 7.023767879 & 2013 \\
\cline { 2 - 8 } & 0.40646951 & 2.665488071 & 5.64944064 & 2.3963502 & 14.696244 & 14.6814982 & 2014 \\
\cline { 2 - 8 } & 0.019338597 & 8.537542344 & 3.87956054 & 8.0379518 & 7.1585402 & 9.601931657 & 2015 \\
\cline { 2 - 8 } & 0.08207085 & 6.291236393 & 3.422569495 & 5.8982354 & 4.0026662 & 2.64214953 & 2016 \\
\hline \multirow{3}{*}{$\mathrm{I}$} & 11.22391796 & 0.662737159 & 1.72228776 & 0.6358459 & 1.5804908 & 3.015896799 & 2013 \\
\cline { 2 - 8 } & 10.16585478 & 2.908042972 & 6.611411841 & 2.8892025 & 1.7066201 & 5.167039374 & 2014 \\
\cline { 2 - 8 } & 11.87701298 & 4.879966566 & 6.729845073 & 4.9101668 & 2.9608697 & 2.440034955 & 2015 \\
\cline { 2 - 8 } & 17.7424437 & 2.717837439 & 2.837677776 & 2.7601978 & 3.2892842 & 5.621788834 & 2016 \\
\hline \multirow{3}{*}{$\mathrm{K}$} & 9.468852659 & 0.068515274 & 3.103902509 & 0.2180303 & 8.6904612 & 1.095976026 & 2013 \\
\cline { 2 - 8 } & 70.72182241 & 0.847337559 & 4.721148677 & 1.6649781 & 13.500811 & 0.835561257 & 2014 \\
\cline { 2 - 7 } & 14.03090946 & 1.932621349 & 0.866510581 & 2.6130502 & 4.7945484 & 10.32707351 & 2015 \\
\cline { 2 - 7 } & 56.62193163 & 1.065858078 & 0.723112981 & 1.2749086 & 17.594975 & 11.50545964 & 2016 \\
\hline \multirow{3}{*}{$\mathrm{N}$} & 24.29736247 & 1.034492368 & 6.922215208 & 1.0521661 & 3.9116337 & 2.236813993 & 2013 \\
\cline { 2 - 7 } & 18.63274851 & 4.27672745 & 6.459803005 & 4.2214194 & 3.0172939 & 3.519253898 & 2014 \\
\cline { 2 - 7 } & 5.163756206 & 5.342147014 & 5.453997959 & 5.1390339 & 5.4972881 & 0.084534393 & 2015 \\
\hline \multirow{2}{*}{10.12896285} & 2.50998816 & 4.341881054 & 2.3518195 & 5.451032 & 1.538273265 & 2016 \\
\hline
\end{tabular}


MAPE RESULTS FOR DMUs FROM 2013 TO 2016

\begin{tabular}{|c|c|c|c|c|c|c|c|}
\hline DMUs & $\begin{array}{c}\text { Fixed } \\
\text { Assets }\end{array}$ & $\begin{array}{c}\text { Cost of } \\
\text { goods } \\
\text { sold }\end{array}$ & $\begin{array}{c}\text { Operating } \\
\text { costs }\end{array}$ & Net sales & Net profits & $\begin{array}{c}\text { Operating } \\
\text { profit }\end{array}$ & $\begin{array}{c}\text { Average } \\
\text { MAPE of } \\
\text { DMUs }\end{array}$ \\
\hline A & 4.36010928 & 4.87406468 & 3.70713106 & 4.02432479 & 17.88379591 & 12.16980399 & 7.83653829 \\
\hline B & 2.47743229 & 1.04510530 & 8.40889750 & 2.31849642 & 14.29877108 & 15.14415115 & 7.28214229 \\
\hline C & 8.87655707 & 0.70152663 & 6.63186796 & 0.66361569 & 4.60535774 & 4.89691443 & 4.39597325 \\
\hline D & 4.73002990 & 4.44549416 & 3.75118440 & 5.11325783 & 21.40818698 & 21.47395873 & 10.15368533 \\
\hline E & 24.92902667 & 4.73076508 & 5.39028142 & 4.16748058 & 4.66217019 & 5.59434859 & 7.28214229 \\
\hline G & 4.10442346 & 4.59368509 & 3.33676821 & 4.68710757 & 14.97044169 & 14.68961141 & 7.73033957 \\
\hline H & 0.15232544 & 4.58111134 & 4.69821604 & 4.29193307 & 8.43490155 & 8.48733682 & 4.39597325 \\
\hline I & 12.75230736 & 2.79214603 & 4.47530561 & 2.79885326 & 2.38431622 & 4.06118999 & 4.87735308 \\
\hline K & 37.71087904 & 0.97858307 & 2.35366869 & 1.44274180 & 11.14519889 & 5.94101761 & 9.92868152 \\
\hline N & 14.55570751 & 3.29083875 & 5.79447431 & 3.19110971 & 4.46931193 & 1.84471889 & 5.52436018 \\
\hline
\end{tabular}

